\title{
Conceptualising globalisation, cultural identity and democracy
}

\author{
Conceituando globalização, \\ identidade cultural e democracia
}

JAN-ERIK LANE*,**

RESUMO: O comunitarismo oferece uma justificativa para a crescente relevância das comunidades. Sua questão-chave é também aquela que a globalização torna altamente relevante, a saber: quem somos nós? Que modo de vida desejamos apoiar? O comunitarismo sublinha a política de respeito mútuo como a reação adequada do Estado democrático ao multiculturalismo. Tal política de respeito mútuo seria verdadeiramente global. O paradoxo da globalização é que ela tanto torna a política comunitária mais saliente quanto exige, ao mesmo tempo, uma política de respeito mútuo que possa reduzir os conflitos étnicos e religiosos. A globalização aumenta a busca pela identidade comunitária. No entanto, uma política de respeito mútuo pode reduzir conflitos entre comunidades e aumentar o respeito global por diferentes culturas, onde diferentes civilizações aceitam um núcleo comum de instituições. PALAVRAS-CHAVE: Cultura; democracia; globalização

ABSTRACT: Communitarianism offers a rationale for the growing relevance of communities. Its key question is also the one that globalisation makes highly relevant, namely: Who are we? What way of life do we wish to support? Communitarianism underlines the politics of mutual respect as the democratic state's proper reaction to multiculturalism. Such a politics of mutual respect would be truly global. The paradox of globalisation is that it both makes communal politics more salient while it at the same time calls for a politics of mutual respect which may reduce ethnic and religious conflict. Globalisation increases the search for communal identity. However, a politics of mutual respect may reduce conflicts between communities and enhance global respect for different cultures, where different civilisations accept a common core of institutions.

KEYWORDS: Culture; democracy; globalization.

JEL Classification: F2; M14.

\footnotetext{
* University of Geneva, Geneva, Switzerland. E-mail: jan_erik_lane@yahoo.co.uk.

** I am grateful to the comments of two anonymous reviewers of this journal.
} 


\section{INTRODUCTION}

The relevance for politics of cultural identities in the form of ethnicity, religion and values has risen during the post Second World War period. First, cultural messages have been formulated more sharply. Second, more compact groups have formed in support of these cultural identities. All over the world several groups having a cultural identity appear to be willing to engage in political action. Time has come to discuss the political implications of the emergence of communal politics. Since globalisation is very much characteristic of this period also, we will pose the question whether globalisation enhances or retards the spread of communal politics. Whereas the interrelationships between globalisation and communal identities and communal groups are complex and not easily entangled, it seems obvious that the democratic state is changing in one direction as a response to communal politics, Cultural identities are based upon a set of more or less coherent as well as more or less realistic ideas, which people accept as the foundation for belonging to a group as well as for taking action. Cultural symbols may be more myths than truth. And cultural groups could display a low level of compactness, as people enter and leave such groups in a fluid fashion. However, cultural identities may become articulate enough to constitute the bedrock for compact groups taking political action. Small but highly compact or large but little compact communal groups may matter much in politics. More and more such groups focus upon rights, or the legal arrangements of the state. And the typical state responses to communal politics include the public recognition of communal groups through the creation of minority rights. The process of globalisation facilitates the drive towards the politics of mutual respect.

As social groups become more and more orientated around cultural identities, first and foremost ethnicity and religion but also universal values, democratic countries need to reflect upon the proper response to this challenge that is in accordance with democratic ideology and constitutionalism. How far can democratic governments employ rights in the new politics of mutual respect? Below I will discuss the pros and cons of such a constitutional policy in order to state the limits of any policy of mutual respect. First, we will examine why globalisation both increases and decreases the relevance of cultural politics. This is a paradox. Second, we will discuss what the democratic state can do for cultural groups without hurting democracy.

\section{GLOBALISATION AND CULTURAL IDENTITY}

It is difficult to pin down globalisation, but at the same time globalisation affects the population in almost every country (Appadurai, 2000). The question: When globalisation proceeds, then what happens to cultural identity?, has two possible answers. Either cultural identity becomes more compact or it becomes less compact. What we wish to argue for is that both answers are true. 
Globalisation fosters the creation of a true world community where people are highly interconnected, at least so in relation to the spread of news. Globalisation is not only the sharing of a high technology society but it also involves acceptance of certain values and ideas. It is unavoidable that the spread of these ideas and values would not reduce cultural diversity. Yet, globalisation is first and foremost an institutional phenomenon being conducive to the creation of a world society ruled by a common set of norms. Globalisation also promotes the convergence around a set of rules and principles, but does globalisation also enhance a global identity of culture, i.e. beliefs and values?

Globalisation involves the increased interaction between many individuals and organisations in different countries. Such an increase in interactions over country borders could not take place without the erection of an institutional structure of rules that facilitate interaction. Thus, a set of international regimes have been created along with the growth of a global economy and polity. The emerging set of international norms could not operate without some degree of common understanding of norms and principles, establishing what are acceptable as well as desirable. The implications of globalisation for culture depend upon how far these common norms and principles will impact upon the beliefs and values of the participants in the global society.

The global society is still in its infancy, but it exists. In the private sector there is a rather broad common understanding of the benefits from a global economy structured in accordance with the institutions of the market economy. The global market economy is an institutional arrangement orientated towards competition between firms across borders and independently of who the owners may be. The key principles of this international order include: deregulation, incorporation, privatisation, new public management as well as regional integration. However, these shared principles are not strong enough to exclude considerable value disagreement about the country economy as well as the means and goals of economic policy-making. The goal of the international market regime is to promote fair competition between private firms and public enterprises in all countries: level the playing field. The accomplishment of this objective requires transparent rules, implemented either in regional co-ordination mechanisms or in international regimes such as e.g. the WTO.

Now, the agreement upon institutions in the international polity has not as yet reached the same level or depth as the convergence upon principles for the international economy. First, one must recognise that democracy is far from the one and only prevailing regime type in the world today, although the democratic form of government has made huge strides forward since 1990. About half of the countries of the world adhere to the democratic values, but far from all of them are to be considered as consolidated democracies.

In the eyes of a considerable portion of the world population the institutions of democracy - human rights - express a Western bias, which in their eyes is a negative. To them there are other values which may take precedence over the Occidental values that surface in a democratic regime, such as for instance Asian or Confucian values or the Muslim religion. It is far from certain that the expansion 
of democracy to more and more countries will simply continue year after year in the $21^{\text {rst }}$ century. In any case, the trend towards more and more agreement about human rights, which form a core in the democratic regime, is a major one with huge consequences for both international relations and domestic politics. The global polity has become more and more firmly institutionalised with a huge set of different rules, some of which are closely connected with human rights in a broad sense. Many of the institutions of the international polity concern the regulation of the member states of this community. One basic principle is non-interference in domestic affairs, which protects authoritarian states against the pressures for democracy.

When Huntington argues that globalisation will link politics with the major civilisations of the world, then he sees only one of the two possible effects of globalisation (Huntington, 1996). To him, globalisation reinforces communal politics to such an extent that there is a large risk for a clash of civilisations. In Huntington's framework, civilisations rest basically upon the various world religions. What needs to be underlined is that globalisation may reduce the tensions between countries adhering to different values, and thus further a global community of people adhering to similar ideas. And the civilisations of the world are in fact far less compact than Huntington pretends. Globalisation may increase the prospects for peace, which Huntington bypasses entirely.

As a consensus about the global economy and polity is emerging, spreading to more and more persons and getting deeper in mutual understanding of principles, then such a major development will impact upon cultures, although this process is slow. Let us explain how globalisation makes nationalism less relevant, reduces the fervour of religion and creates communities of people all over the world sharing the same values.

\section{GLOBALISATION REDUCING NATIONALISM AND COOLING RELIGION}

It may be argued against the future relevance of nationalism that globalisation does not go well together with nationalism in general. In a global economy as well as in global polity nationalism in the classical sense of this ideology has but a minor role. Globalisation undercuts nationalism in two ways: (a) It enhances multicultural societies, which do not support nationalism except in the form of certain minorities embracing xenophobia; (b) It reduces the relevance of the ideology stating the specificity of nations.

Again we have the distinction between group and cultural identity. Globalisation makes groups more heterogeneous and it undermines the belief in and value of separate nations co-existing as compact groups. How could a country proclaim that its nation is special today, especially when the country participates as an equal member in the world community, either in the international economy or in the international polity? And even if a country would cling to a national identity as a belief system, multiculturalism or the growth in social heterogeneity would make such a claim contested within the country. 
At the turn of the $20^{\text {th }}$ century nationalism as an ideology supported by huge groups of people gave the appearance of a belief-system of the future. It seemed both socially relevant and logically appropriate to the political problems at around 1900 , identified by Lenin as "the national question". Large minorities were struggling to attain independence within long overdue empires at the same time as countries that had solved their national question were displaying increasing assertiveness on an international scale. One hundred years later this has all changed, and nationalism in the advanced countries of the world looks more and more as an atavism. Only in certain parts of the world is nationalism still an ideology of the future. It has been argued that nationalism was appropriate to the need of the industrial society. However, this ideology seems to offer little in relation to the post-industrial society (Smith, 1996, 1998).

According to several experts on nationalism, this ideology suited the industrial society well meaning that it was coupled intimately with the process of moderation. Smith states that the theorists who subscribed to the classical modernist paradigm endorsed the ideal of the nation "as a mass participant political culture and as a popular civic-territorial community, into which ever wider strata of the territorial population were drawn through processes of employment, mass education and citizenship". In a modern, i.e. industrial-bureaucratic, era a high level of mass participation was possible; meaning that nations would be the sole political actors and units of government as an expression of self-government of the people (Smith, 1998: 20-21).

Is nationalism dead then in the post-modern society? Not quite, but it has lost its futuristic promise, at least so in the advanced countries characterised by decreasing social compactness and increasing regional integration. When nationalist parties succeed in elections, such as for instance FPÖ in Austria, then this is met with great astonishment. During the post-war period a number of nationalist or populist parties have attempted to attract voters in West European countries as well as in East European countries after democracy was introduced around 1990. However, they have at most received $20 \%$ of the support of the electorate, but certainly not so on many occasions.

Nationalism remains an attractive ideology only in a few Third World countries where ethnies still struggle for recognition and where stable states have never really been put in place. A spectacular nationalist struggle recently took place in East Timor, where an ethnie identified mainly on the basis of Christianity freed itself from Muslim rule by Indonesia. Nationalism in the Third World tends to almost exclusively take the form of separatism, as for instance in Ethiopia, Sri Lanka, Nigeria, Russia, Iraq, Taiwan, Indonesia and China.

When ethnies struggle for recognition in advanced countries, then separatism is far from the only option chosen. As a matter of fact, separatism is so unusual in rich countries that the few cases of nationalism-separatism have received enormous attention: the province of Quebec in Canada and the Basque provinces in Spain. Even in these two examples it is not quite clear whether it is a matter of true separatism or only increased autonomy, at least for the majority of the population living 
in these provinces. In many countries ethnies have chosen other options in order to promote their interests than separatism.

To sum up, nationalism today is either an atavism in First World countries or merely separatism in a few Third World countries. This ideology coming out of the emphasis upon brotherhood - fraternité - in the popular movements initiated by the French revolution is under pressure both inside the country and outside the country by forces set in motion by globalisation. Nationalism as a group phenomenon is being squeezed by forces inside a country-multiculturalism, whereas nationalism as a doctrine continually loses in relevance due to forces outside a countryglobalisation. Globalisation reinforces multiculturalism. Thus, the inside country factor undermining nationalism is to be found in the tendency towards social heterogeneity, which globalisation reinforces through its massive flux of people to and from countries. If nations are no longer compact social groups with one dominant ethnic heritage, then why would states have to be organised as nation-states? The outside country factor that makes the doctrine of nationalism less relevant in a postmodern society is the emergence of regional and global international regimes. If states can have several same legal frameworks to be co-ordinated at levels higher than the national government, then why organise states as nation-states with separate and distinct legal systems?

In reality, these two factors - both the inside and the outside factors - combine to make nationalism out of tune with political realities in the advanced countries. Numerous attempts have been made to mobilise the electorate behind a nationalist party in Western Europe, but they have all failed with the exception of the Austrian FPÖ. One may consider the political career of Enoch Powell as evidence of the impossible task of rendering to nationalism a political future. He launched his campaigns against immigration already in the late 1950s and 1960, when the United Kingdom was far from as socially heterogeneous as it is today, when e.g. London is one of the most ethnically mixed cities of the world. And the sovereignty of Parliament has been replaced by British acceptance of the institutions of the European Union.

How difficult it is to interpret nationalism as a doctrine in global world is amply illustrated in the example of the ambitions of Quebec - the sovereigntyassociation option (Lévesque, 1979). Although there is much talk about independence or sovereignty among the French speaking population in this province, it often seems to be the case that the concept of independence or sovereignty is interpreted by many of these followers as meaning semi-independence or increased autonomy. The province of Quebec would have close relations with other parts of Canada no matter what legal framework is used to define these interactions. Perhaps it would not be a short-cut to leave the Canadian federation just to start building up regional coordination mechanism including a common currency etc.?

In any case, what stops or slows down the Quebec government when pursuing the independence option identified by René Lévesque is the increasing social heterogeneity of the Montreal area, which consists of large ethnic minorities from all over the world. As ethnic fragmentation will only increase in the future, time is 
running out for the sovereignty-association option. But is this alternative really much different from the option of seeking more autonomy within the Canadian federation?

Yet, nationalism remains a powerful force in the Third World where stable states have not yet been put in place. State consolidation may in several Third World countries involve the acceptance of the claims of secessionist movements, as in e.g. Morocco, Nigeria, Congo, Russia, Indonesia and China. The important thing to point out is that globalisation may facilitate this process of separation, not only through the attention given to separatist claims in the global networks. Before we discuss how globalisation may enhance the relevance of nationalism, in several Third World countries, we look at the impact upon religion where one would assume again that the main tendency is that globalisation reduces the strength or intensity of religious creed.

A religion does not lose its relevance due to temporal changes. The major religions of the world have existed for more than one thousand years and they have displayed great capacity to change and adapt to new circumstances. Why, then, would globalisation affect religion one way or the other? The major world religions and their various subforms have their own momentum, conditioned by both their historical evolution and the present environment in which they are embedded. Thus, several of the world religions have to struggle with a long-run downward trend in the development of their followers, their formal and informal membership as it were, whereas two world religions are expanding either in numbers or in intensity of belief. Globalisation when it impacts upon religion as a cultural identity may add or subtract to these two major trends.

Christianity in its three major forms - Catholicism, Protestantism and Greek Orthodoxy — is hardly a religion on expansion today. Although the followers of these religions increase in different parts of the world, it is still the case that they face serious problems in coping with the ever stronger process of secularisation which makes Christians either atheists or very lukewarm believers. One may observe an intensification of Christian belief in some Third World countries, but for Europe it certainly holds that secularisation has made a genuine Christian way of life much less observed than before. Protestant fundamentalism is expanding in Latin America, challenging Catholicism.

The same applies to Buddhism-Confucianism in the Far East, which religion in many countries appears to be on the verge on degenerating into crude forms of polytheism and the worship of amulets. The long experience with Communism in South East Asia has made atheism a wide-spread belief-system, which is also true of Eastern Europe and Central Asia. The fall of Communism as a regime has not led to a major religious revival in either Catholic countries or in Greek Orthodox countries.

Concerning Judaism it may be stated that its sheer number of followers is not that large, no doubt due to the persecution of Jews in Europe before, during and after the Second World War. The large parts of the Jewish population are today concentrated to Israel and to New York. At the same time Judaism is as split as 
Christianity between various forms of this religion, ranging from fundamentalism to lukewarm acceptance of a nominal creed.

Matters are different in relation to Islam and Hinduism. Hinduism is a religion that is increasing in fervour or intensity meaning that its followers tend to observe the norms or the rituals of the religion in question more and more literally. This religion is restricted to India but one may also wish to include its followers in various Indian communities around the world - the Diaspora, which is not small and tends to increase due to migration. Yet, Islam is the fastest growing religion on earth. It receives every day new adherents, expanding southwards in Africa as well as eastwards and north in Asia. Due to migration there are quite sizeable Muslim communities all over Europe and North America. Also the intensity of belief has increased within Islam. Thus, fundamentalist groups stand strong in almost all Muslim countries, which even lukewarm rulers have recognised by accepting Sharia Law and building more Mosques.

To what extent is globalisation a factor that influences these developments of the world religions? The impact of globalisation upon the various religions of the world would be complex, as it facilitates the spread of them across the world but at the same time it cools them down. Globalisation involves a great flux of people, reinforcing the many Diaspora around the world. At the same time it is conducive to more of relativism concerning matters of religion. We actually attribute both the decline of Christianity and the rise of Islam to globalisation, but why would globalisation have opposite impact upon these two world religions? The argument is here that globalisation makes Christianity wishy-washy but reinforces the fervour of Islam, promoting Islamic fundamentalism. Globalisation involves as one of its element the spread of a Western life style, which affects Christian values in one way and Islam in another way.

However, the main impact of globalisation upon religion is that of cooling it down. It is practically impossible to measure the intensity of religious belief - at least on such a grand scale as the entire world, meaning that the cooling down hypothesis cannot be tested strictly speaking. The cooling down effect upon religion from globalisation has two components, one may suggest.

First, globalisation is the increase in interactions between people in various countries. All other things equal, this would reduce mutual suspicion and favour mutual respect and understanding. Countries which isolate themselves in order to reinforce their religious identity will pay a high price for such a policy directed against participation in the international community. Thus, increased transactions promote mutual understanding and lesson the aggressive aspects of religious behaviour. Second, globalisation makes people more materialistic, as it open up the possibility of a more and more people sharing the material benefits of not only peace but also a world division of labour where all economies are governed under a similar institutional framework. Religious fanaticism would endanger the possibility of many poor countries to get a share in the affluence that the world economy promises. It is simply not worth while to opt for religious purity when it would only bring costs to the population. Finally, one may wish to add that globalisation 
involves as one heavy component the increased flux of information about the peoples of the world and their culture. More of knowledge about cultural differences tends to increase cultural relativity, or the willingness to accept other belief systems or values, especially if there is mutual respect. Globalisation needs not be conducive to the clash of civilisations but may instead further a dialogue between cultures, from which understanding and even sympathy may emerge.

\section{GLOBALISATION CREATING WORLDWIDE COMMUNITIES OF LIKE-MINDED}

Values as the foundation for cultural identities are much more flexible than ethnicity and religion meaning that they can easily be acquired and that they can change as a reflection of how times or the spirit of time change. Globalisation fosters the emergence of groups with similar values around the globe, often communicating with each other and influencing each other, despite the existence of political borders and ethnic and religious differences.

There exists enough evidence about this impact of globalisation upon the spread of universal values in relation to two groups, viz. homosexual and lesbian communities. The basic mechanism is that of diffusion: What is accepted in one advanced country could not possibly be rejected in another country. This is not do deny the role that the struggle that each of these two groups have had to go through during the post-war period has had for the improvement of their situation, especially in terms of rights and duties (Adams, Duyvendak and Krouwel, 1999).

Globalisation enhances the diffusion of both values and the claims group may rise in order to promote such values. The diffusion of values and claims may take on very specific forms as when legislation in one country is directly copied in another country. However, most of the time the diffusion of values and claims involves the transfer of general attitudes and ideas, which may be interpreted differently depending upon the country setting. Diffusion may also take place through the many international regimes, some of which are occupied with human rights and the status of collectivities.

Less omnipresent are groups who adhere to so-called post-materialistic values, but globalisation has no doubt contributed to the spread of the values that groups adhering to this culture believes in, namely quality of life and personal integrity, concern for the environment, personal liberty and increased social equality, as well as fairness. The spread of post-materialist values is much linked with affluence, which entails that groups adhering to these values are numerous only in the very rich countries of the world.

Globalisation seems to foster a new confrontation between the left and the right in many countries. Instead of the opposition between capitalism and socialism or the bourgeoisie and the proletariat, the global economy with its visible institutions linked together in a giant flow of transactions day and night seems to split the population or parts of the population into two groups, those who oppose the 
dominance of markets asking for more of regulation nationally or internationally and those who approve of the global market place.

So-called marketers would be the persons who accept and adhere to the global market economy, insisting upon the values of the decentralised market economy, institutionalised in the international market economy where many countries share the same rules governing economic activity. Such groups are to be found among people with various forms of capital assets, and they tend to follow or participate in the global market place, i.e. the various stock markets and the financial institutions, or they follow the events in the global market place with the Internet.

So-called egalitarians would be the groups who somehow oppose the global market economy or demand government regulation and intervention. The opposition to the global market economy comes from a variety of concerns with how markets allocate resources and especially distribute income. Environmental concerns make several groups critical of the global market economy, as such groups would focus upon the pollution problems generally and global warming in particular. To others distributional concerns call for government intervention, as the global market economy is seen as favouring the wealthy and neglecting the havenots. Thus, instead of a confrontation between groups of people with entirely different models of the economic system to be used, there is a polarisation between groups with different images of the role of the state in a global market economy. This involves a basic difference in the perspective upon the state and what government can or should do in terms of governing the economy.

Egalitarians believe in an activist stance on the part of government, having the capacity to steer the economy, at least to some extent. The global market economy is looked upon as negligent in relation to the rights of individuals and groups, where the implementation of these rights often requires strong intervention by the legal authorities. Egalitarians also favour government action in order to control that competition works, taking action against monopolies and trusts. They support the welfare state, as it restricts the market economy by the addition of numerous public programmes based to a considerable extent upon redistributional considerations.

Marketers are in favour of a lesser role for government in the economy. When government intervenes, then it should do in a non-discretionary manner by establishing a fixed institution the consequences of which the participants in the market economy can calculate and predict. State intervention should be kept at a minimum and take the form of independent agencies, staying at arm's length from government. Marketers tend to adhere to the welfare society model, involving considerably less of public programmes and rendering a bigger role for various markets (Wildavsky, 1991). Globalisation not only makes the confrontation between marketers and egalitarians more acute but it also fosters contacts between these groups across country borders. Perhaps the most spectacular event involving this type of confrontation was the meeting in Seattle of the World Trade Organisation in early 2000, when people opposing the new global market economy joined forces during this meeting in order to protest together. However, can one really speak of a common culture among all egalitarians in the world? 
At the same time as globalisation proceeds at an ever increasing speed it seems, one has witnessed a couple of phenomena that involve the strengthening of cultural identities, or more correctly the search for new cultural identities alongside globalisation. In relation to ethnic identity there is the strong emergence of historical minorities or peoples who were left behind in the modernisation process. In relation to religion we have growth of the Muslim Diaspora in Western Europe as well as the coming of Hindi nationalism. And one may add here as an example of new culture identity the role that religion plays in US or Israeli politics today.

The historical minorities: During the last decades peoples who had been marginalised during several centuries have been more successful than ever before in claiming rights. In the debate about the nature of collective rights the claims of peoples like the Eskimos, the Samis, the many Indian tribes in North and South America, the Aborigines and the Maoris have figured prominently. And in several cases these claims have been successful meaning that they have to some extent been recognised and accepted by legal authorities or the state.

The rights of ancient peoples concern several things, from economic and social claims to political ones. The most spectacular successes won in and outside of courts by these so-called historical minorities refer to economic rights of a collective nature, i.e. either to land, the use of land or the compensation for old wrong doings concerning land or other economically valuable assets such as fishing rights, etc. For historical minorities representation rights are no doubt very important, but rights which directly involve monetary values or monetary compensation are even more vital for these socially deprived communities. Globalisation has made the struggle of historical minorities to have their ancient rights respected easier in several ways.

The Claims for Compensation: In a few major settlements minorities have secured huge compensation for wrongdoings in the past, which underlines the existence of a legal world community protecting ethnic and religious groups to some extent. Here, we have the final regulation of the Jewish accounts within Swiss banks, the payment of compensation to prison workers in Germany and the acknowledgments of Aboriginal and Maori demands in Australia and New Zealand. One may regard the introduction of an International Criminal Court in 1999 as a further development towards the strengthening of the international community.

The Muslim Diaspora: The growth of the Muslim Diaspora in Western Europe to sizeable minorities of hundred of thousands or millions of people in several countries has changed these societies in a very short period of time towards multiculturalism. The sharp increase in social heterogeneity both from a religious and ethnic point of view has been accentuated by the emphasis upon a Muslim identity with attending rights. The assimilation strategy is only employed to a limited extent, or in so far as it may guarantee equal citizen rights. Cultural separateness is instead more and more the option opted for with attending claims to state recognition and government support. 
In classical theory of social heterogeneity the distinction between the image of the melting-pot and the conception of the ghetto played a major role in outlining two alternative strategies as to how the majority population and the minorities would interact. This distinction appears to be far less applicable today than in relation to yesterday. The emergence of huge Muslim disappears in Western Europe shows that minorities may actually combine both strategy options of assimilation and differentiation.

The most visible symbol of the assertiveness of the Muslim Diaspora is the construction of many new mosques, of which some are almost as large as the famous mosques in the Arab world. If local government in the past had second thoughts about offering land for such projects, things are less complicated now, partly because having access to a mosque in one's vicinity is regarded as a collective right of this minority. However, the claims of the Muslim Diaspora are not limited to the right to religion or worship.

The Muslim Diaspora tend to demand also other kinds of collective rights, related one way or the other to the practice of their religion or to the protection of their culture and languages. Thus, Arab minorities for instance focus upon their access to the Arabic language in the form of for example educational facilities of their children or government support for the cultural activities or the translation of book etc. What various Muslim minorities - Arab or non-Arab - seek first and foremost are symbols of state recognition of their special cultural status, but often such recognition is a means to acquiring financial support of one kind or another.

Rise of Hindi nationalism: The creation of India and Pakistan in 1947 was followed by a war between the two new states as well as by civil war between the Hindi and Muslim communities within the two countries. However, after this no doubt very bloody birth of the two new states things cooled down, especially as the Congress Party rulers in India emphasised the secular nature of the state. This strategy worked well for a number of years until the support for the nationalist party BJP started to increase in the 1980s. At the same time as the BJP has gone from been a small party in the shadow of the hegemony of the Congress Party to forming their own simply majority government in year 2000, India has responded the globalisation challenge by opening up its economy and reducing regulations of the import substitution kind. The surging support for BJP is - at least to some extent - a search for a cultural identity that the Congress Party in its modernisation efforts downplayed. Is Hindi nationalism a religiously or ethnically based phenomenon? Both would be the correct answer, but the emphasis is upon religion, as BJP mobilises the votes for both Hinduism as a religion but not so much the Hindi language, which would be too dangerous given the language diversity of India.

One needs to distinguish between stimulus and response when it comes to globalisation and its impact upon culture. As a stimulus globalisation reduces cultural diversity and also cultural extremism. But a reaction to globalisation may be the search for a stronger cultural identity. Globalisation evens out cultural diversity pushing people towards the willing or unwilling acceptance of the global market economy and its institutions as well as the international polity with its leaning 
towards human rights. However, these stimuli from globalisation upon each single country may well provoke a counter-reaction leading to a search for a deeper cultural commitment. How these two effects - stimulus and response - work out in each country depends upon other conditions, which means that in some countries the response, or the search for cultural identity, may turn out to be especially strong.

Globalisation being a complex if not an amorphous phenomenon would in all circumstances have a set of several impacts upon societies and their political systems. The one single specific effect that globalisation has is to increase the relevance of groups rights. The idea of collective rights has long been criticised if not rejected as an incoherent addition to the idea of human rights. However, the more globalisation works out its consequences, the more the idea of group rights appears to be accepted. The combination of these three things - judicialisation, internationalisation and the emphasis upon justice - contribute to the increased legitimacy of the talk about group rights. Finally, when these three trends combine with the growing social heterogeneity as a result of globalisation, then multiculturalism with contain a strong dose of collective rights.

\section{THE POLITICS OF MUTUAL RESPECT}

The politics of mutual respect is a constitutional policy using rights in order to accommodate a society with multicultural groups including historical minorities, immigrant groups, refugees as well as religious sects inter alia, which all orientated on the basis of cultural identity. It covers all kinds of mechanisms that enhance the position of minorities coming from ethnic or religious communities: group rights, consultation procedures, territorial decentralisation, veto players, state recognition, financial support, judicial protection, etc. It rejects the concept of democracy as an adversarial game between majority and minority where the winner takes all.

One fundamental argument in favour of collective rights states that even a complete implementation of universal individual human rights cannot fully protect weak minorities. Thus, group rights constitute a means to an end. The standard example is the native Indian or Aboriginal populations around the globe, who have not been able to protect themselves and their life-style against stronger groups, despite the recognition of human rights in the countries in question. Only if such weak minorities can exercise collective rights, can they withstand the subtle or invisible pressures from the majority - at least so it is argued. This is the means argument. Collective rights would constitute an institutional mechanism for the empowerment of minority groups, especially historical minorities.

The ends argument is somewhat different, as groups rights would be an expression of cultural identities and not a means to their enhancement. These groups' rights would embody the identity of minorities, as without them they would cease to exist. Group rights are vital to minorities, as these rights constitute them so to speak. Minorities may wish to have collective rights introduced, despite the counterargument that they are messy, difficult to implement and little efficient in order to 
enhance the interests of the individuals adhering to the minority. Group rights may be of little value as means to acceptable assimilation or proper differentiation, but they could be the constitution of their identity. Thus, whether collective rights work as means to whatever ends conceivable are beside the point, as they enter the essence of the cultural identity of the group.

Since collective rights are highly contested, the method by which they could become accepted as law has been much debated. Basically, there are two methods available for the introduction of group rights: legislation or judicial interpretation in the form of precedents. The initiative often today rests with judges. In public international law group rights have received more and more attention resulting in codification of such rights. However, in national legislation one observes a great reluctance to engage in the recognition of collective rights. The empty space is often filled by judicial activism, whereby case law establishes collective rights as important additions to individual human rights.

Recently, also politicians have paid more and more attention to group rights, deliberating over whether they could be recognised in a codified form as additions to already existing human rights legislation. However, both case law and codified legislation face a grave problem in relation to collective rights, namely: Who acts on behalf of a group when implementing collective rights, doing what for which members of the group?

Some argue that this problem is insoluble and severely restricts the use of collective rights. Others state that it presents difficulties that can only be solved on a piecemeal basis. It is a task for the politics of mutual respect to find solutions to this problem. The new politics of mutual respect sounds like a version of consociational theory, suggesting institutional mechanisms for so-called divided societies (Lijphart, 1977). However, it is not the same as consociationalism. Instead of the sharp distinction between homogeneous and heterogeneous societies, to which correspond two types of democracy (majoritarian and consensus), there is only one society model focusing upon a multicultural structure where lots of groups live together although they have different ways of life. One may wish to include also gay and lesbian communities, bypassing the entire issue whether sexual orientations are more socially defined than biologically derived or not.

The policy dilemmas of a politics of mutual respect include that it is very difficult to draw a distinction between the policy of promoting a culture and the policy of recognising a culture. Whereas the latter seems morally acceptable, the former may take on very ugly features of rent-seeking, using the state coffers for group egoistic materialism. If the latter occurs, then the politics of mutual respect may degenerate into a politics of difference where groups behave opportunistically in order to maximise their share of benefits from various public policies.

Democracy only entails two rules when a minimum conception is laid down. The first rule specifies political equality, i.e. it allocates one vote to each person. The second rule requires that group decision-making be based upon an aggregation mechanism which derives the collective choice from the preferences of the choice participants in accordance with either the simple majority rule or some qualified 
majority rule including as a theoretical possibility unanimity. Constitutional democracy goes beyond such a minimum definition of democracy adding a number of institutions to these two minimum ones.

The theory of procedural liberalism implies that a number of rules have to be added to the minimum set of institutions. A constitutional state would according to this theory be based upon an overlapping consensus concerning first and foremost what a well-ordered society requires in terms of proper citizenship. It is a matter of a strictly limited theory of rights, "Altogether the possession of these basic liberties specifies the common and guaranteed status of equal citizens in a well-ordered democratic society" (Rawls, 1996: 335). Rawls presents a long list of such basic liberties which constitute the core of political liberalism in his interpretation, but it is hardly a very precise one: equal political liberties, freedom of thought, free and informed application of the principles of justice, some form of representative democratic regime, freedom of political speech and press, freedom of assembly, the liberty and integrity of the person, and the rights and liberties covered by the rule of law (Rawls, 1996: 334-35).

What political liberalism in Rawls' interpretation contains is simply the set of negative rights in standard public international law. They have always been considered as the core of the doctrine of constitutionalism, which though contains more than the set of negative rights. Does Rawls also include positive rights in his conception of political liberalism? The answer is: YES, but they are not to be entered into the constitution of a state adhering to political liberalism. He states: "In the first instance, then, the constitution is seen as a just political procedure which incorporates the equal political liberties and seeks to assure their fair value so that the processes of political decision are open to all on a roughly equal basis. The constitution must also guarantee freedom of thought if the exercise of these liberties is to be free and informal" (Rawls, 1996: 337).

Actually, such a constitution would only contain the individual rights that have been considered as a logical consequence of the acceptance of the minimum definition of democracy as decision-making based upon one man one vote and simple majority voting, at least to some extent. What Rawls requires of a liberal constitutional state is the implementation of the civil and political rights included in the standard indices on human rights, which are also considered to constitute indices upon democracy. In other words, the Rawls' definition of political liberalism and a constitutional democracy is quite trivial, as nobody would reject it. But people may wish to add more rights to the Rawls' set, especially if they advocate the politics of mutual respect.

It is perhaps not astonishing that Rawls himself wishes to add more rights to this thin definition of a democratic state. Thus, he adds that his well-known difference principle is valid also for a country adhering political liberalism in the sense that it should be applied in the social and economic policy-making of the country without reservations. However, for some reason or other the difference principle is not to be placed in the constitution, where for instance it could constitute the bed- 
rock for so-called positive rights, i.e. claims about what government ought to do in the form of public policies promoting employment, education and health.

Since the difference principle, if valid and if put into practice, is a most encompassing principle for creating rights between the state and society, both individual or collective rights, one would expect it to be given a constitutional status, if indeed it is to be a guiding principle of the state. Let us quote from Rawls again: "Although delegates have a notion of just and effective legislation, the second principle of justice, which is part of the content of this notion, is not incorporated into the constitution itself. Indeed, the history of successful constitutions suggests that principles to regulate economic and social inequalities, and other distributive principles, are generally not suitable as constitutional restrictions" (Rawls, 1996: 337). As an historical analysis of the coming and going of constitutions this statement is hardly true, as many governments have put in positive rights into their state constitutions, and some of these are to be found in states where constitutional stability is the case. Perhaps the difference principle is simply too radical or controversial in order to be put into a constitutions, meaning that its validity is maybe less selfevident than Rawls believes?

In any case, the argument for restricting the constitution of a liberal state to the set of negative rights is with Rawls political efficiency, i.e. the easiness with which representative bodies and other political assemblies can arrive at a decision. To take a final quote: "The emphasis is first on the constitution as specifying a just and workable political procedure so far without any constitutional restrictions on what the legislative outcome may be" (Rawls, 1996: 337). We will argue that a workable decision-making process is a most relevant and important consideration when one talks about rights, especially as one moves to include much more rights than Rawls did in the constitution of a democratic state.

\section{DEMOCRACY IN MULTICULTURAL SOCIETIES - A GLOBAL CHALLENGE}

Democracy as a political regime is linked up with citizen participation as well as rights. According to the well-known framework of R. Dahl for the analysis of the concept(s) of democracy the participation aspect may be confronted with the rights aspect. In populist democracy there is a minimum of citizen rights, as what is essential is that each and every one is guaranteed the right to participate on the basic of the formula: One Man (Woman) - One vote. In Madisonian democracy the set of rights becomes plentiful, as checks and balances are considered the essence of a democratic state (Dahl, 1956). Consociational democracy may be regarded as a species of Madisonian democracy, as it also calls for the institutionalisation of democracy by means of rights which guarantee minorities influence or autonomy (Lijphart, 1999). The demand of cultural groups for state recognition - politics of mutual respect - enters the debate on the meaning of democracy 
today with a focus upon rights, individual ones as well as collective ones (Taylor and Gutman, 1994).

The emergence of communal politics on the basis of the mobilisation of groups with cultural identities rather than economic interests as with associational groups calls for the rethinking of political rights, especially collective rights (Kymlicka, 1995). The nature of group rights is a contested matter, as it is widely believed that collective rights may come into conflict with individual rights. Individual rights are strongly entrenched in the democratic state ideology, sanctioned by the many declarations of human rights. How far can a democratic government go in the acceptance of group rights?

The interpretation of the nature of democracy in a post-modern society involves consideration of both participation (Rousseau) and rights (Madison). We argue that communal groups primarily target rights, or the introduction of new entitlements surrounding their minority status. The concept of citizenship has become a vehicle for this new debate on democracy and minorities (Kymlicka and Norman, 2000). Just as democracy may be developed by collective rights, so citizenship may become more complex and minority orientated (van Gunsteren, 1998). As communal ties grow stronger in the societies around the world along with the rise of multiculturalism, governments may wish to employ the legal machinery of the state to recognise this trend, the politics of mutual respect resulting in the formation of group rights (Avineri and de-Shalit, 1992). Collective rights can be seen as a conflict resolution mechanism. However, paradoxically too much of group rights may also become the vehicle of severe political conflicts in the state, both ex ante and ex post. To some scholars there is something fundamentally suspect about group or collective rights, and they would wish to send a warning to democratic governments when they engage in the politics of mutual respect (Posner, 1999). We will argue that group rights are not problematic so much from the point of view of the logic of justice, but - we emphasise - political efficiency limits their usefulness.

Group rights are much spoken of in relation to multicultural societies, as they could potentially constitute a new and comprehensive mechanism of conflict solution in these societies. Collective rights range from mere state recognition of the existence of all minorities to elaborate schemes of legislation involving a say if not veto powers on the part of minorities. The theory of group rights remains to be developed in a more precise manner, but it may be said that it faces two great challenges, namely: (1) the clarification of the concept of collective rights as distinct from individual rights; (2) the elaboration of how groups rights can be made to work in the judicial system, or how they are to be implemented. Following the classical Hohfeld analysis of rights as claims, liberties, competencies and immunities (Hohfeld, 2000), we will first attempt to pin down what groups rights could amount to.

One should make a sharp distinction between two kinds of group rights. On the one hand there are group rights which are merely the sum of individual rights like the right of women to equal treatment in relation to men with regard to various things like salary, office, representation, etc. On the other hand there are group rights which are not reducible to individual rights like the position of minority as- 
sets like language, land, fishing, etc. One key to understanding what group or collective rights entail is to unpack which groups or collectivities we are talking about, using the Hohfeld scheme. Thus, we have:

a) Immunities: These are the rights that are strictly speaking not negotiable and they cannot be restricted through legislation. In relation to collective rights immunities would be the right to survival and happiness of minorities, involving prohibitions against genocide and discrimination. Groups have been active in calling for constitutional recognition of their special character in the form of rules about the heterogeneity in society, describing it as comprising different nations or ethnies or religious groups. What immunity would call for is the continued existence of the group(s) in question.

In democratic constitutions one often reads such immunities in relation to historical minorities meaning groups that have lived on the territory of the country since time immemorial. But can or should they also be enacted in relation to immigrant groups? Immunities, however, typically take the form of individual rights for instance in the form of guarantees about human rights concerning life, nondiscrimination, physical protection and freedom of conscience and speech. The key question is whether these immunities need to be guaranteed in relation to groups. The standard argument against group immunities is that if individual immunities really are respected, then group immunities are superfluous.

Against the argument about the priority of individual immunities over group immunities it has been argued that group immunities secure something in addition to individual immunities, namely the cultural identity of the group in question. It is not enough for an ethnic or religious group to know that any person has certain inalienable rights. What needs to be secured as immunity is the special nature of the group in question. The counter-argument is that groups may very well look after themselves and protect themselves without state interference, if individual immunities are put in place properly. This is very much a question of how groups secure their survival, i.e. whether small groups can survive in societies where one majority dominates without using formal mechanisms of subordination.

The argument about the insufficiency of the establishment of individual immunities is contained in the rejection of the politics of assimilation typical of the theory of the melting-pot society (Glazer, 1997). The politics of assimilation, it is stated, always works itself out with a bias in favour of the dominant group. It is assimilation on their terms that is aimed at in the melting-pot society. If minorities wish to maintain their identities, then they have to have a stronger net of protection, including the public recognition of the separateness of many minority groups, excluding or hindering assimilation.

Now, strictly speaking there are not many immunities even in democratic states, as liberties tend to be circumscribed by lots of conditions. Thus, life as well as liberty is restricted by many rules which change over time. Some states accept the death penalty and all states implement the principle that property that is in the public domain can be expropriated. Free speech also has its limits. Groups may well argue that the introduction of group immunities would make it more difficult for governments 
to restrict individual liberties, or at least force governments to make these limitations transparent and subject to legislation as well as judicial interpretation. Often groups seek only a state recognition of their right to exist, which may not mean much concretely but such immunity could be of immense symbolic import.

b) Competencies: These are the rights that bodies or organs in the state exercise when they deal with decisions of various kinds. Thus, federalism is a theory about the division of competencies along territorial lines. Constitutions tend to be very meticulous about the specification of the organs of the state and their competencies. Thus, constitutions also instruct the judiciary to handle the problems of the interpretation of the constitution which often involve conflicting views about competencies. Groups may demand that the bodies or organs given various forms of competencies be made up of groups or minorities.

Groups demanding better constitutional protection of rights may focus upon competencies especially when groups are concentrated to certain areas of the country in question, then groups tend to demand increased autonomy of the relevant territory, covering a plethora of competencies linked with federalism, home rule, regionalism, local government, etc. However, when groups are spread out evenly over the land of the country in question, then groups may demand special representation rights. These may include various mechanisms of voice for the groups in decision-making such as minimum representation, the right to be heard on certain issues as well as possibility to deliver a veto on some of these as well as the competency to appoint certain officials etc.

Competencies may be framed in a highly complex manner in order to come close to what various groups demand. However, strictly speaking many competencies are not per se group rights or collective rights. Territorial competencies may foster the interests of groups, because it happens to be the case that certain groups can take charge of these competencies through for instance their overrepresentation in certain areas of the country. But, federalism for instance is not inherently a system of group rights.

Competencies may also be awarded on a functional basis. Thus, rights involving competencies over policy-making or implementation may be provided for interest organisations or for communities. Typically, functional competencies tend to belong to the informal system of government variously labelled e.g. "zuilen", "corporatism", "lobbyism", "clientelism" etc. Sometimes, functional competencies become part of law or even the constitution as when groups are given a specific position on certain policy domains. Thus, communal groups may be given a special role in cultural policy-making.

Special representation rights belong to set of public competencies, which offer collective rights to groups. They may take a variety of forms from representation within Parliament, over the creation of special consulting boards to the general accomplishment of Proporz, or the proportionality of all key groups, all over the state, not only in representative assemblies but also in the structure of positions in the bureaucracy. These rights may involve the initiation of hearing on/and veto concerning policy-making or implementation. 
c) Liberties: Such rights would provide groups with insurance that they can act as they wish. Thus groups would know that they could e.g. organise their own religious meetings, speak their language and follow their ways of life. Liberties are not immunities though. Thus, liberties could be restricted by means of legislation. Yet, putting them down explicitly may constitute a protection for the groups in question. Again, one may discuss whether such collective liberties could not be covered by a broad set of individual liberties.

Groups protect their way of life, or at least they try. Minorities with a cultural identity that is different from the culture of the majority typically pursue two strategies or some combination of them: On the one hand minorities attempt assimilation in order to enhance their chances to compete on an equal footing with other groups. On the other hand minorities may seek differentiation or recognition of their special nature in order that their cultural identity be strengthened. Liberties as rights belong more to the second strategy than the first one.

Opting for more of liberties entails that minorities wish to employ the state to set up fences towards other groups in order to demarcate where a group may do as it wishes. Liberties may include religious behaviour but also ethnicity. Furthermore, liberties are often sought by groups adhering to universal values, for instance homosexual groups or lesbian ones. Liberties for some carry no corresponding obligation on others, except that they must respect what they decide to do.

Liberties may be infringed upon by ordinary legislation. Liberties are never absolute but result from ongoing considerations about what may be left to individuals or groups to decide themselves. Do group liberties constitute an addition to individual liberties? According to the theory that group rights are superfluous, if individual rights are in place, the liberties of groups could always be decomposed into individual liberties. Take the case of religious liberties, for instance the liberty to dress as one wish, for instance carrying clothes with a religious tone.

When Muslim groups constituting minorities in Western Europe demand the liberty to dress in accordance with they way of life, for instance the liberty of Muslim children to hide their hair when they are in school, then more is involved than simply the individual liberty to dress as one wishes, given the restriction that one cannot wear offensive cloths or no cloths at all, which would also constitute an offence to the ordinary opinion. When Muslim children hide their hair collectively, then it is more a group action with strong political implications than the mere circumstance that a few persons happen to do the very same thing. If this group liberty is accepted, then it would constitute a threat against the religious neutrality of public education, or at least so it has been argued by a few courts in West European countries.

d) Claims: These are the rights that groups would act upon in order to demand things from the state, such as resources, constituting obligations on the part of the state towards the groups. Here, we find a number of group claims that have emerged recently such as financial support for activities expressing or reinforcing the way of life of minorities. In reality, there is hardly any end to what groups may claim from the state and the ministry of finance. 
Claims would constitute the other side of the coin in relation to liberties, as they constitute obligations, if accepted as rightful that is. There is presently a tendency on the part of both groups and governments to move from the acceptance of liberties to the promotion of claims. Thus, groups wish to have not only the freedom to act in accordance with their ways of life but they also want the economic support of the state in order to make their ways of life flourish.

A constitutional democracy is a system of government where the will of the people is aggregated and expressed under numerous institutions, some of which restrict the capacity of a majority to take decisions. The politics of mutual respect adds a new layer to the constitutional state by designing rules that enhance mutual respect between the various social groups, especially collective rights. The goal of this new kind of constitutional policy is to enhance mutual recognition and toleration but not to promote assimilation. Its Achilles' heal is, however, that it may become so complicated that it reduces efficiency in interaction between groups the transaction cost argument.

\section{TRANSACTION COSTS}

The main objection against a policy of mutual recognition based upon an extensive use of collective rights is that it results in new forms of discrimination against individuals, either within the group itself or between groups. This is not the major disadvantage in our view. It is efficiency that is hurt by too much politics of mutual respect. The advantage is the cultural recognition that comes out of such a policy, but there is a price to be paid and it may run high. Life becomes too complicated, not only in society but also in the state. Let us explain this disadvantage by focusing upon how democracy may snare itself by too much constitutionalism or rights hurting participation, majority rule and the capacity to decide.

Claims may be driven very far. Thus, each minority could claim a plethora of support and recognition from the state. First, it is argued that such a social structure where each minority would live it own life supported by its own organisations enhancing ways of life corresponding to its cultural identity would result in a macro structure for that society which is not desirable. It would create a stalled society with a high level of intergroup conflict. Such a macro structure would make impossible the ideal of assimilation typical of a melting-point society, where groups compete under universal institutions. This is the macro argument contra group claims.

Second, in such a macro structure it would be difficult to individuals to claim fully individual rights. Indeed such a macro structure could pose a threat towards general human rights in the form of immunities. An individual in a democratic society must have the right to equal treatment when it comes to jobs and opportunities. However, a macro structure could entail that such elementary micro rights could not be fulfilled, as all jobs and opportunities would belong to groups, decid- 
ing over them in terms of their strategy to favour their ways of life. This is the essence of the micro argument contra group claims.

Constitutionalism, or the theory about the constitutional state as government under the Rule of Law, has been married to democracy during the $20^{\text {th }}$ century. When a democratic regime is put into a constitutionalist framework, then a set of rights is added to the minimum definition stated above. The politics of mutual respect and its model of a constitutional democracy should be confronted with the exigencies that flow from the notion of political efficiency. Now, the politics of mutual respect demands a sharp increase in the set of rights, which are to be allocated to not only individuals but also groups. What is the efficiency costs involved?

Thick constitutionalism entails the use of decision-making procedures that restrict the unfettered reign of the simple majority institution. Here we find ideas about rules that — at least so it is argued — increase political stability: (i) a critical role for veto players; (ii) qualified majority decision-making; (iii) legal review of both executive and legislative acts; (iv) bargaining and/or arbitration procedures; (v) immunities; (vi) recognition of group rights; (vii) federalism or decentralisation and devolution.

The main argument in favour of thick constitutionalism is that its employment enhances rationality in political life, avoiding political instability in the aggregation of preferences like the paradox (Arrow, 1963). Simple majority voting could generate voting cycles resulting in intransitive collective outcomes, if not restraining by the putting into place of institutions that make the expression of the popular will more difficult. The recent wealth of rational choice articles show that institutions enhance stability in decision-making. However, it does not say that thick institutionalism comes with a substantial cost, namely the reduction in efficiency in public decision-making.

There is hardly any limit to how thick a constitution can be made in a constitutional democracy, as under the headings above (i) - (vii) we find lots of possible institutional devices. However, the price to be paid in the form of a less efficient democracy increases the more devices are introduced. The introduction massively of collective rights could follow the logic outlined above. In the beginning such a constitutional policy could enhance democracy, as the benefits would be high and the costs low. However, after a certain amount has been created, such a constitutional policy would run into efficiency losses. We are trading rights off against efficiency. Democracies always face the task of making decisions for the entire group, initiating policies or implementing them. Rights increase the probability of a deadlock, which would reduce political efficiency.

Transaction costs include the effort and time devoted to the making and implementation of decisions. The drawback of the politics of mutual respect between communities is that societies would be confronted with a sharp rise in transaction costs when practicing democracy. In effect, transaction costs set a limit upon how far governments may wish to go in introducing the mechanisms protecting ethnic and religious communities. 


\section{CONCLUSION}

The theory of communal relationships - communitarianism — offers a philosophical rationale for the growing understanding of communities, which almost seems to make these groups more important socially or politically than associations. In communitarianism the focus is almost exclusively at ethnies and not nations besides religious groups and community groups. The key question that communitarianism tries to answer is also the one that globalisation makes highly relevant, namely: Who are we? What way of life do we wish to support? How do social relations define our identity? One may not wish to agree with the strong theses of communitarianism, but it is undeniable that this new philosophy emerging during the last twenty years has increased understanding of community and communal interactions.

Communitarianism underlines cultural identities at the expense of universal orientations. Thus, people are so intimately connected with a culture that they are so to speak constituted by the culture in question or embedded in such a particular culture. The strong thesis about cultural identity defining persons is at odds with much evidence that shows people could decide to leave one culture and adopt another as well as that persons often adhere to universal values more or less at the same time at they identify with a particular culture. In response to the communitarian claim that cultural identities are stronger than value orientations various scholars have begun to develop a theory about the politics of mutual respect, which would be the democratic state's proper reaction to multiculturalism. Such a politics of mutual respect would be truly global, especially if it is to work in a period of rapid globalisation. At first it enhances democracy but when driven further it counteracts democracy reducing the efficiency of a larger group to take decisions in relation to its many subgroups.

The paradox of globalisation is that it both makes communal politics more salient while it at the same time calls for a politics of mutual respect which may reduce ethnic and religious conflict. Communal heterogeneity will increase as a function of globalisation and the search for communal identity will also intensify. However, a politics of mutual respect may reduce conflicts between communities and enhance a global respect for different cultures, where different civilisations accept a common core of institutions. The risk with the politics of mutual respect is that it leads to immense transaction costs in democratic decision-making.

\section{REFERENCES}

ADAMS, B.D., DUYVENDAK, J.W. and KROUWEL, A. (eds.) (1999) The Global Challenge of Gay and Lesbian Politics. Philadelphia, PA: Temple University Press.

APPADURAI, A. (2000) Modernity at Large: Cultural Dimensions of Globalisation. Minneapolis: University of Minnesota Press.

ARROW, K.J. (1963) Social Choice and Individual Values. New York: Wiley. 
AVINERI, S. and DE-SHALIT, A. (1992) Communitarianism and Individualism. Oxford University Press.

DAHL, R.A. (1956) A Preface to Democratic Theory. Chicago, IL: University of Chicago Press.

DEVIGNE, R. (1994) Recasting Conservatism. New Haven: Yale University Press.

GLAZER, N. (1997) We Are All Multiculturals Now. Cambridge, MA: Harvard University Press.

HOHFELD, W. (2000) Fundamental Legal Conceptions. Aldershot: Dartmouth.

HUNTINGTON, S.P. (1996) The Clash of Civilizations and the Remaking of World Order. New York: Touchstone.

KYMLICKA, W. (ed.) (1995) The Rights of Minority Cultures. Oxford: Oxford University Press.

KYMLICKA W. and NORMAN, W. (2000), Citizenship in Diverse Societies, Oxford University Press. LÉVESQUE, R. (1979) My Québec. Toronto: Methuen.

LIJPHART, A. (1977) Democracy in Plural Societies: A Comparative Exploration. New Haven, CT: Yale University Press.

LIJPHART, A. (1999) Patterns of Democracy: Government Forms and Performance in thirty-six Countries. New Haven, CT: Yale University Press.

POSNER, R.A. (1999) The Problematics of Moral and Legal Theory, The Belknap Press of Harvard University Press.

RAWLS, J. (1996), Political Liberalism. New York, NY: Columbia University Press.

SMITH, A.D. (1996) Nations and Nationalism in a Global Era. Cambridge: Polity Press.

SMITH, A.D. (1998) Nationalism and Modernism. London: Routledge.

TAYLOR, C.L. and GUTMAN, A. (eds.) (1994) Multiculturalism. Princeton, NJ: Princeton University Press.

VAN GUNSTEREN, H.R. (1998) A Theory of Citizenship. Boulder, CO: Westview Press.

WILDAVSKY, A. (1991) The Rise of Radical Egalitarianism. Washington, DC: American University Press. 